\title{
19. PALYNOSTRATIGRAPHY OF CRETACEOUS SEDIMENTS FROM SITE 387, WESTERN BERMUDA RISE
}

\author{
Daniel Habib, Department of Earth and Environmental Sciences, Queens College, New York
}

\begin{abstract}
Twenty-five samples, representing a section approximately 303 meters thick, were studied from Site 387 in the western North Atlantic in order to determine the stratigraphic distribution of sporomorphs and dinoflagellate cysts. Eight dinoflagellate zones and four sporomorph zones (two subzones) were distinguished which permit the dating of the section by correlation with the zonations established for the reference section at Site 105. Palynomorphs date the section of Site 387 as ranging from Berriasian/ lower Valanginian (stratigraphic level of Core 49) to Cenomanian (Core 30 ).

The palynofacies of the Cretaceous section at Site 387 is the same as that for other previously investigated sites in the western North Atlantic. Neocomian palynomorph assemblages are dominated by dinoflagellate species of Druggidium and Biorbifera (B. johnewingii) and by sporomorph taxa represented by bisaccate pollen, relatively smooth and small pteriodophyte spores, and Classopollis torosus. Middle Cretaceous assemblages reflect the stratigraphic (and evolutionary) succession of angiosperm pollen species with respect to both species diversity and abundance of specimens. Dinoflagellates are less abundant as a palynomorph group and are represented to a large extent by cavate cysts with a peridinioid outline.
\end{abstract}

\section{INTRODUCTION}

Twenty-five samples from the Lower and Middle Cretaceous section at Site 387 were investigated in order to determine the stratigraphy of sporomorphs and dinoflagellate cysts, and to compare the stratigraphy with that of the corresponding section at Site 105 (Figure 1). Site 387 was drilled on the western Bermuda Rise at $32^{\circ} 19.2^{\prime} \mathrm{N}$ latitude and $67^{\circ} 40^{\prime} \mathrm{W}$ longitude (Tucholke, Vogt, et al., 1975). A Lower and Middle Cretaceous section approximately 303 meters thick was recovered, extending from approximately 489 meters (stratigraphic level of Core 30) to approximately 792 meters (Core 49) beneath the sea floor (Figure 2). This section rests directly on basalt (stratigraphic level of Core 50) and is immediately overlain by red clay (Core 29) essentially devoid of palynomorphs.

The individual dinoflagellate and sporomorph zonations established for the reference section at Site 105 (Habib, 1977) were distinguished at Site 387 as well. On the basis of correlation with the zonations at Site 105 (Figure 3), the palyniferous interval at Site 387 is dated as ranging from Berriasian/lower Valanginian (Core 49) to Cenomanian (Core 30). Although fewer samples were studied from Site 387, the same dinoflagellate zones and sporomorph zones could be distinguished.

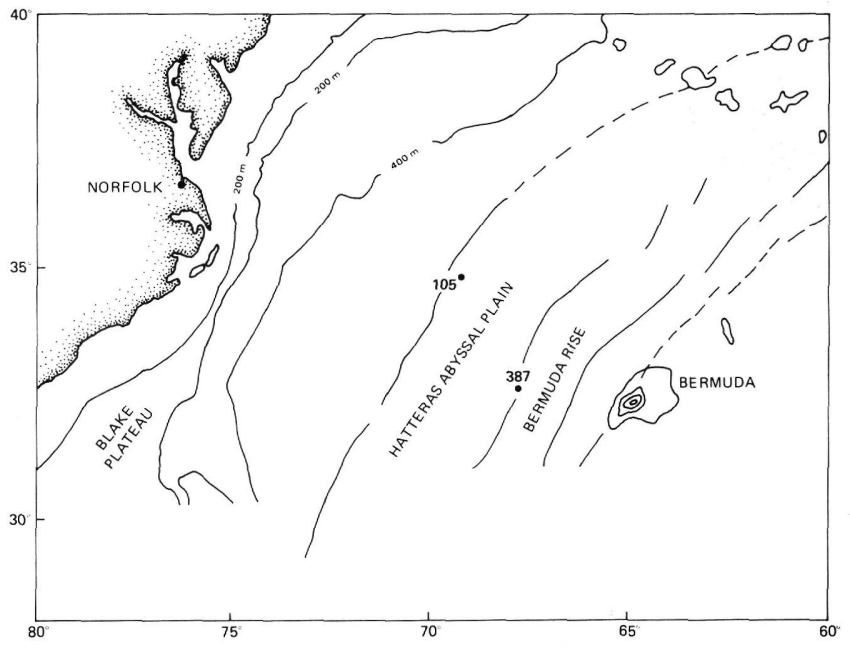

Figure 1. Geographic positions of Sites 387 and 105 in the western North Atlantic.

The generalized lithostratigraphy of Site 387 is summarized in Figure 2. Two major lithofacies are evident; a lower, largely Neocomian, nannofossil limestone and chalk facies, and a higher Middle Cretaceous, carbonaceous clay and mudstone facies. These facies are evident elsewhere in western North Atlantic Lower Cretaceous sections, for example, at Sites 99, 101, and 105 (Hollister, Ewing, et al., 1972). The 


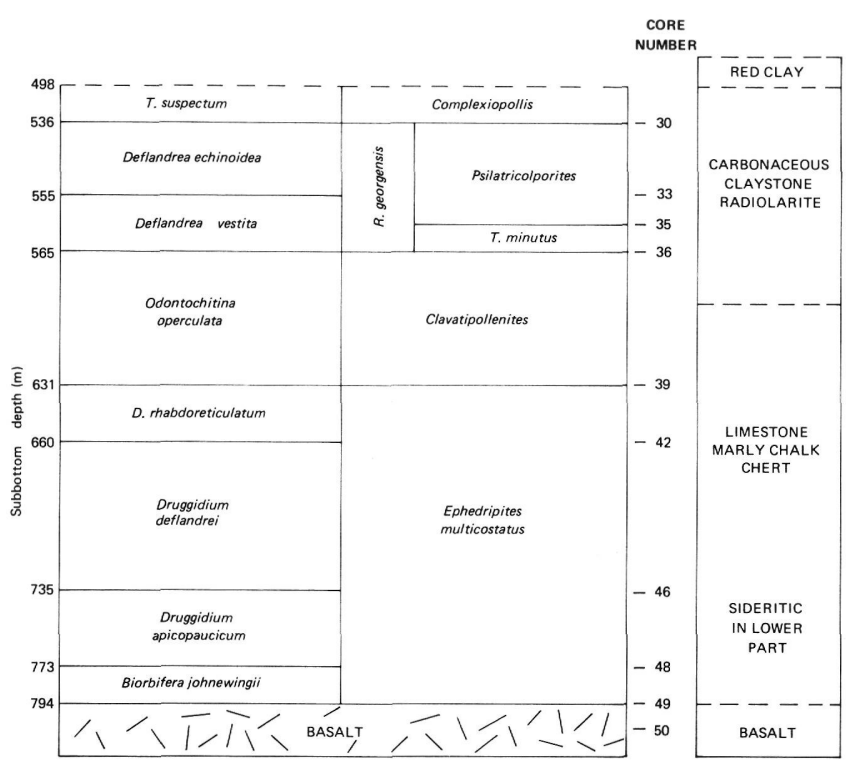

Figure 2. Palynostratigraphic zonation at Site 387. Dinoflagellate zonation at left; sporomorph zonation at right. Generalized lithostratigraphy shown at far right.

change in facies at Site 387 (Tucholke, Vogt, et al., 1975) and elsewhere (Hollister, Ewing, et al., 1972) has been correlated with seismic reflection Horizon $\beta$. The facies change occurs within the Odontochitina operculata/Clavatipollenites zones in the western North Atlantic (Figure 2; Habib, 1977).

\section{PALYNOSTRATIGRAPHY}

The palynomorph assemblages at Site 387 are generally less diverse than those of Sites 105, 99, and 101. Although fewer species are present, most assemblages are nonetheless highly fossiliferous with respect to numbers of specimens.

The aspect of the palynoflora at Site 387 is essentially the same as that of the other western North Atlantic sites. Neocomian dinoflagellate assemblages are characterized by an abundance of fossils representing zonal taxa, for example, species of Druggidium and Biorbifera johnewingii Habib. The more abundant sporomorph taxa in the Neocomian sections are characterized by species in the following three morphological groups.

1) Classopollis torosus (Reissinger).

2 ) Bisaccate pollen grains, principally species of Pinuspollenites, for example $P$. comptonensis Kemp, $P$. potomacensis Brenner, P. minimus (Couper), and $\mathrm{Al}$ isporites (A. bilateralis Rouse).

3) Pteriodophyte spores, psilate or lightly ornamented, and generally smaller than $50 \mu \mathrm{m}$ in size, for example, species of Cyathidites, Dictyophyllidites, Gleicheniidites, Deltoidospora.

Classopollis torosus and species of Pinuspollenites dominate the Neocomian sporomorph assemblages. Other pollen species which occur less frequently, but which are stratigraphically persistent, include $V i$ treisporites pallidus (Reissinger), Ginkgocycadophytus nitidus (Balme), Eucommiidites minor Groot and Penny, Parvisaccites radiatus Couper, Exesipollenites tumulus Balme, and Ephedripites multicostatus Brenner. Noteworthy is the paucity and absence of the larger and more highly ornamented spore species, especially those of the genera Appendiciporites, Cicatricosisporites, Pilosisporites, and Trilobosporites. Where these species do occur (e.g., Cicatricosisporites potomacensis Brenner), they form less than one per cent of the assemblage and are stratigraphically discontinuous.

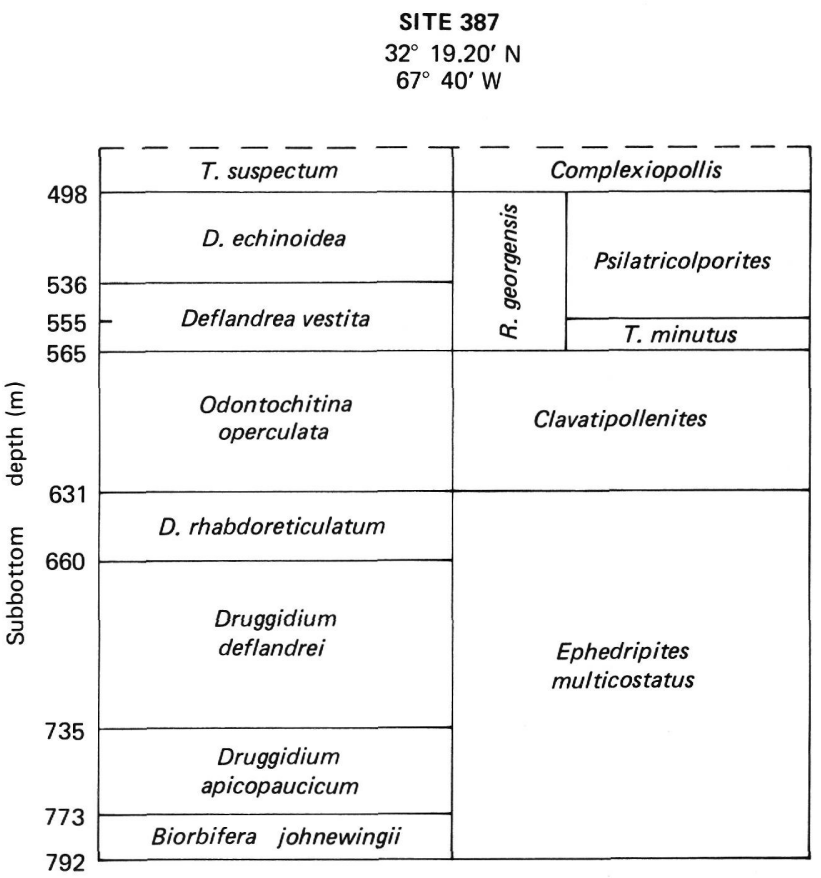

Figure 3. Comparison of palynostratigraphic zonations at Sites 387 with those of the reference section at Site 105. 
Middle Cretaceous sporomorph assemblages in the western North Atlantic record the increasing diversification of pollen taxa of angiospermous affinity in the morphological succession represented first by tectate monosulcate grains, and then by prolate triaperturate (tricolpate), oblate tricolporate, and oblate triporate (Normapolles) grains (cf. Doyle, 1969). This sequence permits the correlation of western North Atlantic sections with the Cretaceous nonmarine facies of the U.S. Atlantic coastal plain (Habib, 1977). Middle Cretaceous dinoflagellate assemblages reflect the replacement of Druggidium by cavate species of peridinioid outline (e.g., Deflandrea vestita [Brideaux] Palaeohystrichophora infusorioides Deflandre and Cookson, Subtilisphaera perlucida [Alberti]) and chorate cysts, e.g. Hystrichosphaeridium arundum Eisenack and Cookson.

Small acritarchs, generally smaller than $10 \mu \mathrm{m}$ in diameter and mainly of the Micrhystridium-Veryhachium group, occur in abundance throughout the Lower and Middle Cretaceous of the western North Atlantic.

\section{PALYNOMORPH ZONATION}

The palynostratigraphic zonations are based upon, and correlated with, the reference zonations established for Site 105 (Figure 3). Paleontological ages of the zones at Site 105 have been taken mainly from nannofossils (Thierstein, 1976) and foraminifers (Luterbacher, 1972), as well as dinoflagellates (Habib, 1976, 1977).

\section{Dinoflagellate Zones}

\section{Biorbifera johnewingii Zone}

Sample: 387-49-1, 127-129 cm.

Age: Berriasian/lower Valanginian.

The palynomorph assemblage is rich, with respect to both sporomorphs and dinoflagellate cysts. The absence of Amphorula metaelliptica Dodekova in the single sample representing this zone at Site 387 suggests that it may not be older than upper Berriasian or lower Valanginian. Biorbifera johnewingii Habib comprises 14 per cent of the total palynomorph assemblage (dinoflagellate cysts and sporomorphs) of 20 species.

2. Druggidium apicopaucicum Zone

Sample: 387-48-1, 56-58 cm.

Age: Valanginian.

The dinoflagellate Druggidium apicopaucicum Habib and the sporomorphs Classopollis torosus and Pinuspollenites comptonensis are most abundant. The assemblage is rich, and is represented by 23 species.

3. Druggidium deflandrei Zone

Sample: 387-46-1, 74-75 cm.

Age: upper Valanginian/Hauterivian.

The dinoflagellate flora is represented by few species and many specimens. Druggidium deflandrei (Millioud) forms a high percentage of the palynomorph assemblage in the single sample investigated.

4. Druggidium rhabdoreticulatum Zone

Samples: $387-42-1,75-77 \mathrm{~cm}$.

$387-41-1,112-114 \mathrm{~cm}$.
$387-41-1,70-71 \mathrm{~cm}$.

$387-40-2,108-109 \mathrm{~cm}$.

$387-40-2,52-54 \mathrm{~cm}$.

387-40-1, 146-148 cm.

Age: Hauterivian or Barremian.

Dinoflagellates in the samples are diverse and abundant. Druggidium rhabdoreticulatum Habib is well represented, making up 8 to 25 per cent of the palynomorph assemblage. The zone is represented best at Site 387 , because of its greater thickness and the larger number of samples studied. Habib (1976) originally described the Druggidium rhabdoreticulatum Zone as a subzone. Habib (1977) elevated it to the status of zone, based on its geographic range in the western North Atlantic.

D. deflandrei always occurs in higher percentages than D. rhabdoreticulatum in the Druggidium rhabdoreticulatum Zone. At Site 387, Wallodinium krutzschii (Alberti) occurs in its highest percentages within this zone.

5. Odontochitina operculata Zone

Samples: $387-39-2,12-13 \mathrm{~cm}$.

$387-38-1,98-100 \mathrm{~cm}$.

387-38-1, 0-2 cm.

$387-37-4,101-103 \mathrm{~cm}$.

$387-37-2,132-134 \mathrm{~cm}$.

Age: upper Hauterivian/Barremian-lower/ middle Albian.

Odontochitina operculata (Wetzel) is stratigraphically persistent but scarce in the investigated samples. The species is represented mostly by opercula. The palynomorph assemblages are composed mainly of sporomorphs. The most abundant dinoflagellate species are Druggidium deflandrei and D. rhabdoreticulatum.

Habib (1977) described two subzones for the Odontochitina operculata Zone in the North Atlantic. They are not recognized at Site 387, however, owing to the apparent absence of Phoberocysta neocomica (Alberti) in this section.

6. Deflandrea vestita Zone

Samples: $387-36-4,86-88 \mathrm{~cm}$.

$387-36-2,86-88 \mathrm{~cm}$.

$387-35-5,79-81 \mathrm{~cm}$.

$387-35-2,97-99 \mathrm{~cm}$.

$387-34-4,76-78 \mathrm{~cm}$.

387-34-1, 121-123 cm.

Age: Albian.

The palynomorph assemblages in the Deflandrea vestita Zone are dominated by sporomorph taxa. However, Deflandrea vestita (Brideaux) and other dinoflagellates representative of this zone, for example, Palaeohystrichophora infusorioides Deflandre, are present in the investigated samples.

7. Deflandrea echinoidea Zone

Samples: $387-33-1,135-136 \mathrm{~cm}$.

$387-32-6,130-131 \mathrm{~cm}$.

$387-32-3,5-7 \mathrm{~cm}$.

387-31-1, 148-150 cm.

Age: upper Albian/Cenomanian.

The Deflandrea echinoidea Zone is highly fossiliferous, especially with respect to sporomorphs. 
8. Trithyrodinium suspectum Zone Sample: $387-30-1,34-36 \mathrm{~cm}$. Age: Cenomanian.

The Trithyrodinium suspectum Zone is poorly fossiliferous, but contains its diagnostic taxa (Habib, 1977).

\section{Sporomorph Zones}

1. Ephedripites multicostatus Zone

At Site 387 and elsewhere in the western North Atlantic, the Ephedripites multicostatus Zone is equivalent to the Biorbifera johnewingii-Druggidium rhabdoreticulatum dinoflagellate zones. The nominate species forms from 2 to 3 per cent of the total palynomorph assemblages in the investigated samples. The most commonly occurring sporomorph species are, among others, Pinuspollenites comptonensis and Classopollis torosus.

2. Clavatipollenites Zone

The Clavatipollenites Zone is represented in the same samples containing the Odontochitina operculata dinoflagellate Zone. The lowest samples contain Clavatipollenites $\mathrm{sp}$., a smooth tectate-imperforate species, and is joined in the higher samples, e.g., 387-38-1, 0-2 $\mathrm{cm}, 387-37-4,101-103 \mathrm{~cm}$., by Clavatipollenites hughesii Couper and other angiospermous sulcate species, for example, Liliacidites peroreticulatus (Brenner), L. trichotomosulcatus Singh. Classopollis torosus and Pinuspollenites comptonensis continue to be the most common sporomorph taxa in the palynomorph assemblages. Parvisaccites radiatus Couper, a species which occurs at the bottom of the investigated section, becomes more common in the Clavatipollenites Zone.

\section{Retitricolpites georgensis Zone}

Retitricolpites georgensis Brenner varies from 4 per cent of the total palynomorph assemblage in the lowest sample, $387-36-4,86-88 \mathrm{~cm}$, up to 23 per cent in other samples. In the western North Atlantic, the Retitricolpites georgensis Zone corresponds to the Deflandrea vestita-Deflandrea echinoidea dinoflagellate zones.

The two subzones distinguished at Site 105 for the Retitricolpites georgensis Zone are recognized at Site 387 as well. The lower subzone, the Tricolpites minutus Subzone, is represented solely by Core 36 in Samples 387-36-4, 86-88 cm and 387-36-2, 86-88 cm. Tricolpites minutus (Brenner) and $R$. georgensis occur, along with other tricolpate pollen species, for example, Retitricolpites magnificus Habib, $R$. sphaeroides Pierce, Psilatricolpites psilatus Pierce, and Tricolpites micromunus (Groot and Penny). Classopollis torosus and species of Pinuspolenites dominate the palynoflora in the stratigraphically lower sample, to form 47 per cent of the palynomorph assemblage as opposed to 7 per cent for all triaperturate angiosperm species. Clavatipollenites hughesii constitutes 4 per cent. However, in the stratigraphically higher sample, 387-36-2, 86-88 $\mathrm{cm}$, the triaperturate species form a total of 38 per cent of all palynomorphs, or about the same percentage as C. torosus (20 per cent) and Pinuspollenites spp (16 per cent) combined.

The Tricolpites minutus Subzone has been dated as Albian (Habib, 1977).
The higher subzone, the Psilatricolporites Subzone, is represented by the following samples:

$387-35-5,79-81 \mathrm{~cm}$.

$387-35-2,97-99 \mathrm{~cm}$.

$387-34-4,76-78 \mathrm{~cm}$.

$387-34-1,121-123 \mathrm{~cm}$.

$387-33-1,135-136 \mathrm{~cm}$.

$387-32-6,130131 \mathrm{~cm}$.

$387-32-3,5-7 \mathrm{~cm}$.

387-31-1, 148-150 cm.

Psilatricolporites sp. (Habib, 1977) constitutes from 1 to 3 per cent of the palynomorph assemblages. In contrast to the palynoflora of the Tricolpites minutus Subzone, the triaperturate pollen species characteristic of the Retitricolpites georgensis Zone clearly dominate the sporomorph flora of the Psilatricolporites Subzone, and constitute a substantial percentage (about 40 per cent) of all palynomorphs. On the other hand, Classopollis torosus makes up 4 per cent or less of the assemblages from this subzone.

The Psilatricolporites Subzone is considered to be of Albian/Cenomanian age. Eucommiidites minor has its highest occurrence in the stratigraphic interval represented by Core 34 . This sporomorph species is considered not to range above the Albian (Williams, 1975).

\section{Complexiopollis Zone}

The Complexiopollis Zone is represented by a single sample, $387-30-1,34-36 \mathrm{~cm}$, and is equivalent to the Trithyrodinium suspectum dinoflagellate Zone. It is characterized by the occurrence of two Normapolles species, Complexiopollis sp. and Atlantopollis sp. The occurrence of Classopollis torosus, although rare, as well as Exesipollenites tumulus Balme and Retitricolpites georgensis, suggests that this sample is not younger than Cenomanian.

\section{DISCUSSION}

Figure 3 shows the correlation of the two palynomorph zonations at Site 387 with the zonations of the reference section at Site 105. All of the dinoflagellate zones and sporomorph zones (and subzones) described originally from Site 105 were also distinguished at Site 387. However, the stratigraphic positions of boundaries between many of the zones at Site 387 cannot be considered to be accurately placed because of the relatively small number of samples studied. Nevertheless, it is apparent that the succession of zones in each zonation is the same for the two sites.

The thickness of each zone at Site 387 appears to be proportional to its thickness at Site 105. However, two exceptions are noted. The Druggidium deflandrei dinoflagellate Zone appears to be disproportionately thicker at Site 387. Also, the Deflandrea vestita dinoflagellate Zone, and equivalent Retitricolpites georgensis sporomorph Zone (Tricolpites minutus Subzone), appears to be disproportionately thinner at this site.

\section{ACKNOWLEDGMENTS}

D. H. Krinsley reviewed the manuscript. This study was supported by a grant from the National Science Foundation, GA-39991. 


\section{REFERENCES}

Doyle, J. A., 1969. Cretaceous angiosperm pollen of the Atlantic Coastal Plain and its evolutionary significance: $J$. Arnold Arboretum, v. 50, p. 1-35.

Habib, D., 1976. Neocomian dinoflagellate zonation in the western North Atlantic: Micropaleontology, v. 21, p. 373392.

1977. Comparison of Lower and Middle Cretaceous palynostratigraphic zonations in the western North Atlantic: Symp. Strat. Micropaleontology Atlantic Basins and Borderlands, Proc., Elsevier Publishing Co., p. 341367.

Hollister, C. D., Ewing, J. I., et al., 1972. Initial Reports of the Deep Sea Drilling Project, v. 11: Washington (U.S. Government Printing Office).
Luterbacher, H. P., 1972. Foraminifera from the Lower Cretaceous and Upper Jurassic of the northwestern Atlantic. In Hollister, C. D., Ewing, J. I., et al., Initial Reports of the Deep Sea Drilling Project, v. 11: Washington (U.S. Government Printing Office), p. 561-593.

Thierstein, H. R., 1976. Calcareous nannoplankton biostratigraphy at the Jurassic-Cretaceous boundary: Bur. Rech. Géol. Min., Men., v. 86, p. 85-94.

Tucholke, B., Vogt, P., et al., 1975. Glomar Challenger drills in the North Atlantic: Geotimes, p. 18-21.

Williams, G. L., 1975. Dinoflagellate and spore stratigraphy of the Mesozoic-Cenozoic, offshore eastern Canada: Geol. Surv. Canada, Paper 74-30, v. 2, p. 107-146. 